\title{
KWESTIA BOGACTWA I UBÓSTWA W KOŚCIELE IMPERIALNYM NA ZACHODZIE W IV I V WIEKU Próba syntezy zagadnienia
}

Dla chrześcijan I-II wieku kwestia bogactwa i ubóstwa związana była z ewangelicznymi ideałami wspólnoty: dobrowolnym wyrzeczeniem się dóbr tego świata (Łk 12, 33; Mt 19, 21. 27), wspólnotą dóbr materialnych (Dz 4, 32$5,11)$ oraz wspólnotą uczuć wyrażaną przez relacje braterskie (Dz 4, 32; Rz 5, 12-21; 2Kor 1,7 ; Hbr 10, 33; 1P 4, 13). Ów potrójny ideał życia wspólnotowego najdoskonalej był zrealizowany w życiu Jezusa Chrystusa (Dz 3, 14; Flp 2, $6-11 ; \mathrm{Kol} 1,15)^{1}$. Późniejsza, chrześcijańska próba dostosowywania się do wymienionych wzorów związanych z właściwym sposobem nabywania - posiadania oraz używania dóbr materialnych była niewątpliwie łatwiejsza w małych grupach chrześcijańskich, istniejących do III wieku², niż w masowym Kościele imperialnym IV czy V wieku. W pierwszych dwóch wiekach chrześcijaństwa wypracowano dwie zasadnicze opinie na temat dóbr materialnych: praktyczno-pozytywną (podkreślającą pochodzenie dóbr materialnych od Boga, dlatego postulującą właściwe/dobre ich używanie) lub ascetyczno-negatywną (podkreślającą niebezpieczeństwo bogactw dla życia duchowego, stąd postulującą ich wyrzeczenie się przez wybór życia ubogiego na wzór życia Jezusa Chrystusa) ${ }^{3}$.

Od momentu uzyskania osobowości prawnej w Cesarstwie Rzymskim w 312 r. Kościół chrześcijański, szczególnie w części zachodniej Imperium

\footnotetext{
${ }^{1}$ Por. J. Leclercq, «Il s'est fait pauvre». Le Christ modèle de pauvreté volontaire d'après les Pères, VS 117 (1967) 501-518.

${ }^{2}$ Por. V. Grossi, La chiesa preconstantiniana di fronte a la povertà, $\mathrm{w}$ : L'annuncio del Regno ai poveri. Atti della XV Sessione di formazione ecumenica organizzata dal Segretariato attività ecumeniche (La Mendola - Trento, 30 luglio - 7 agosto 1977), Torino 1978, 69-101.

${ }^{3}$ Por. T. Mauro - P. Alieto, Retto uso delle ricchezze nella tradizione patristica. Clemente d'Alessandria, Basilio di Cesarea, Gregorio di Nazianzo, Gregorio di Nissa, Giovanni Crisostomo, Ambrogio di Milano, Agostino d'Ippona, Cromazio d'Aquileia, Torino 1985; E. Dal Covolo, Riccheza e povertà nei primi tre secoli della Chiesa, w: Humanitas classica e sapientia cristiana, ed. S. Felici, Roma 1992, 259-274; A. Rodziński, Bogactwo i ubóstwo w świetle myśli chrześcijańskiej pierwszych trzech stuleci, VoxP 16 (1996) z. 30-31, 85-90; A.G. Hamman, Partage avec le pauvre, Les Pères dans la foi 72, Paris 1998; D. Kasprzak, Bogactwo i bieda w starożytności chrześcijańskiej, w: Bogactwo i bieda. Próba refleksji humanistycznej, red. R. Borkowski, Kraków 2004, 25-32.
} 
Romanum, stawał w kolejnych wiekach przed szeregiem nowych zjawisk społecznych (m.in.: załamanie się osadnictwa rzymskiego, zmniejszanie się liczby ludności na większości jego terenów, proces porzucania ziemi uprawnej, zjawisko patronatu, powstawanie majątków kościelnych, skrócenie średniej długości życia, znaczne niedożywienie i ogólne pogorszenie się warunków życia ludności $)^{4}$. Jednak dla Ojców Kościoła i pisarzy wczesnochrześcijańskich IV i V wieku, podobnie jak we wcześniejszym okresie, podstawowym kościelnym odniesieniem do zagadnień bogactwa i ubóstwa pozostawała perspektywa chrześcijańskiej soteriologii. W okresie patrystycznym (I-VII wiek) nie można jeszcze mówić o określonych kościelnych doktrynach socjalno-ekonomicznych czy politycznych na podstawie opinii poszczególnych pisarzy wczesnochrześcijańskich ${ }^{5}$.

Niemniej nauczanie niektórych teologów IV i V wieku wywarło znaczący wpływ na kształtowanie się późniejszych doktryn społecznych w Kościele katolickim. W niniejszym artykule pragnę ukazać podejście do zagadnienia bogactwa i ubóstwa w ujęciu reprezentatywnych teologów chrześcijańskich w Kościele Zachodnim w IV i V wieku, zarówno tych ortodoksyjnych (wy-

${ }^{4}$ Por. J. Śrutwa, Majatek kościelny i jego funkcja społeczna w Afryce Łacińskiej II-V wieku, RTK 28 (1981) z. 4, 5-28; G. Ryś, Majątek kościelny w starożytnym prawodawstwie synodalnym, w: Charisteria Tito Górski oblata. Studia i rozprawy ofiarowane profesorowi Tytusowi Górskiemu., red. S. Stabryła - R.M. Zawadzki, Kraków 2003, 219-227; M. McCormick, Narodziny Europy. Korzenie gospodarki europejskiej 300-900, thum. A. Bugaj-Z. Dalewski - J. Lang - I. Skrzypczak, Warszawa 2007, 38-50.

${ }^{5}$ Por. M. G. Mara, Richezza e povertà nel cristianesimo primitivo, Roma 1991, 25. Bibliografia tematyczna związana z kwestią własności, bogactwa i ubóstwa w okresie patrystycznym jest bardzo obszerna. Z najważniejszych prac na ten temat należy wymienić: L. Lallemand, Histoire de la charité, vol. 1-4, Paris 1902-1912; E. Bruck, Kirchenväter und soziales Erbrecht: Wanderungen religiöser Ideen durch die Rechte der östlichen und westlichen Welt, Heidelberg 1956, 1-75; Riches et pauvres dans l'Église ancienne, ed. Q.J. France - A. Hamman, Paris 1962; M. Hengel, Property and riches in the early Church: aspects of a social history of early Christianity, London 1974; J. de Santa Ana, Good news to the poor: the challenge of the poor in the history of the Church, Maryknoll (NY) 1979; C. Lindberg, Through a glass darkly: a history of the Church's vision of the poor and poverty, „The Ecumenical Review” 33 (1981) 37-52; AA. VV., Per foramen acus. Il cristianesimo antico di fronte alla pericope evangelica del „giovane ricco”, Studia Patristica Mediolanensia 14, Milano 1986; J.A.T. McGuckin, The vine and the Elm Tree: the patristic interpretation of Jesus teaching on wealth, w: The Church and wealth, ed. W.J. Sheils - D. Wood, Studies in Church History 24, Oxford 1987, 1-14; T.D. Hanks, Poor, poverty, w: Anchor Bible Dictionary, V, New York 1992, 403-424; M.J. De Vinne, The advocacy of empty bellies: episcopal representation of the poor in the late Empire, Stanford 1995; D. Janes, God and gold in late Antiquity, Cambridge 1998; P. Brown, Poverty and leadership in the later Roman Empire, Hanover (NH) 2002; D. Caner, Wandering begging monks: spiritual authority and the promotion of monasticism in Late Antiquity, The Transformation of the Classical Heritage 33, Berkeley 2002; Les Pères de l'Église et la voix des pauvres. Actes du $11^{e}$ colloque de La Rochelle (2-4 septembre 2005), ed. P.G. Delage, La Rochelle (France) 2006; Wealth and poverty in early Church and society. Holy Cross studies in patristic theology and history, ed. S.R. Holman, Grand Rapids 2008. 
brałem dwóch Doktorów Kościoła Zachodniego: św. Ambrożego - biskupa Mediolanu i św. Augustyna - biskupa Hippony) oraz przedstawicieli ortodoksyjnego monastycyzmu, jak i heterodoksyjnego ascetycznego ruchu pelagian.

\section{UZNANIE PRAWA WŁASNOŚCI DÓBR MATERIALNYCH}

W III wieku chrześcijaństwo wypracowało już trzy zróżnicowane opinie na temat prawa własności i prawa do użytkowania dóbr materialnych: optymistyczną, pesymistyczną i realistyczna. Myśl optymistyczna uważała bogactwo za narzędzie do uświęcenia i za dowód opieki Bożej w zamian za pobożne życie. W ujęciu pesymistycznym bogactwo było uznawane za grzech, a posiadanie bogactw skazywałoby na potępienie. Pogląd realistyczny i tym samym umiarkowany, najbardziej rozpowszechniony w IV wieku, uznawał dobra materialne za chciane przez Boga i jako takie dane człowiekowi, za czynnik godziwy i konieczny do życia doczesnego ${ }^{6}$. Zróżnicowanie tych poglądów wynikało z wpływu na myśl pisarzy chrześcijańskich zarówno ze strony Starego Testamentu i szerzej rozumianego judaizmu, jak i myśli pogańskiej greckiej i rzymskiej; w nauce Chrystusa byłyby jedynie podstawy moralne prawa własności. Prawo własności przynależy do porządku naturalnego, a nie prawa objawionego, jednak nie stoi z nim w sprzeczności, bo źródłem obu tych praw jest ten sam Bóg7.

Jednym z pierwszych teoretyków prawa własności w Kościele doby cesarstwa na Zachodzie był biskup Mediolanu - św. Ambroży (339-397) ${ }^{8}$. W swoim traktacie Historia Nabota uczy, że źródłem wszelkiego dobra jest Bóg, stąd dobra same w sobie są - dobre, gdyż są dziełem Boga i posiadają takie zastosowanie, jakie im nadał Bóg, czyli są przeznaczone dla wszystkich ludzi ${ }^{9}$.

${ }^{6}$ Por. H. Gulbinowicz, Etyczne poglady św. Ambrożego na dobra materialne i prawo własności, „Studia Warmińskie” 1 (1964) 262. Omawiając postawę realistyczną w stosunku do dóbr materialnych H. Gulbinowicz stwierdza (tamże, s. 262), że „Postawa realistyczna, po bliższej analizie wskazuje na przedłużenie myśli i nauk zawartych w Torze i u Proroków ST, którzy brali w obronę biednych i nie uważali dóbr materialnych za zło in se. Dlatego też nie nakazywali od nich uciekać, ani tym bardziej nimi gardzić. Sądzili, że posiadanie ich, nie stanowi samo przez się dostatecznej przyczyny wiecznego potępienia. Przedstawiciele poglądu realistycznego żądali od tych, którzy posiadali dobra materialne, by czynili z nich dobry użytek, tzn. stosowali w praktyce codziennego życia nakazy miłości bliźniego podane przez Chrystusa (Mt 5, 7; 10, 42; Łk 6, 36)”; zob. M. Żywczyński, Poglady chrześcijan IV wieku na nierówność majatkowa w świecie, ŻM 3 (1956) 39-47.

${ }^{7}$ Por. P. Christophe, L'usage chrétien du droit de propriété dans l'Écriture et la tradition patristique, Paris 1964, 19-20.

${ }^{8}$ Szerzej na temat idei życia społecznego według Ambrożego z Mediolanu por. V.R. Vasey, The social ideas in the works of. St. Ambrose. A study on „De Nabuthae”, SEA 17, Roma 1982 (odnośnie własności prywatnej u Ambrożego zob. szczególnie rozdz. III, s. 105-182).

${ }^{9}$ Por. Ambrosius, De Nabuthae 1, 2, ed. F. Gori, w: Sancti Ambrosii Episcopi Mediolanensis Opera (= SAEMO), vol. 6, Milano - Roma 1985, 130-132, tłum. R. Pankiewicz: Historia Nabota, PSP 35, Warszawa 1986, 26-27: „Świat został stworzony ku pożytkowi wszystkich, dla bogatych 
Dlatego dobra materialne, jak np. ziemia, są dobrami przyrodzonymi człowieka $^{10}$. Dobra, jakimi dysponuje człowiek są podzielone według Ambrożego na: dobra duszy, dobra ciała i dobra zewnętrzne ${ }^{11}$. Dobra duszy i ciała każdy człowiek otrzymał na swe wyłączne posiadanie. Natomiast dobra zewnętrzne są konieczne w tym życiu doczesnym, a istnieją po to, aby człowiek zarządzał nimi rozsądnie, i aby dopomóc człowiekowi w osiągnięciu królestwa niebieskiego $^{12}$. Służą temu celowi, kiedy ich właściciel, oprócz zaspokojenia własnych potrzeb, wspiera nimi również potrzebujących. Inaczej są bezużyteczne i jako takie marnowane ${ }^{13}$. Kiedy natomiast posiadane bogactwa wzbudzają jedynie żądzę zachłanności posiadania kolejnych dóbr materialnych, które są przeznaczane wyłącznie na spełnianie namiętności chciwca, wtedy stają się źródłem grzechu, gdyż oddalają takiego człowieka od wypełniania woli Boga $^{14}$. Ambroży nie odrzucał prawa do własności prywatnej, wręcz przeciwnie stwierdzał, że kto nie przestrzega takiego prawa - łamie tym samym nie tylko prawo natury, lecz prawo Boże $\mathrm{e}^{15}$. Jednak z drugiej strony bogaty, który nie pomaga biednym czy potrzebującym - kierując się w życiu tylko swoją korzyścią, będzie przez Boga odrzucony ${ }^{16}$.

jak i dla biednych. Na jakiej podstawie tylko sobie przypisujecie prawo do posiadania ziemi? Matka - natura nie zna ludzi bogatych, i biednymi wszystkich wydaje na świat. [...] Nie zna wielkości majątków naszych zamykając w grobie ta, która żyjącym pobożnie niczego nie zabiera, bogatym w jednej chwili wszystko odbierze. A zatem, jeśli nie zna natura różnic, gdy na świat przychodzimy, nie zna także, gdy zeń odchodzimy".

${ }^{10}$ Por. tamże, SAEMO 6, 130, PSP 35, 26: „Jakim prawem usuwacie z przyrodzonej własności współwłaściciela i przywłaszczacie sobie jego ziemię".

${ }^{11}$ Por. Gulbinowicz, Etyczne poglady św. Ambrożego, s. 264-265.

${ }^{12}$ Por. Ambrosius, De Nabuthae 7, 37, SAEMO 6, 158, PSP 35, 38: „Czemuż to burzysz spichrze? Pochwalam ciebie, gdy więcej niż inni dbasz o swoje zboże i kiedy je szczelnie ogradzasz, by zabezpieczyć się przed złodziejami. Ukryj zboże w sercu ludzi ubogich, gdzie nie dostanie go żaden robak, a długie przechowywanie nie zmarnuje".

${ }^{13}$ Por. tamże 12, 52, SAEMO 6, 172, PSP 35, 44: „Podobnie nienaruszane bogactwo nie przynosi pożytku, a bezczynność czyni je nieprzydatnym dla tego, do kogo należy".

${ }^{14}$ Por. tamże 2, 5, SAEMO 6, 134-136, PSP 35, 28: „Jednego nazwiemy ubogim z uwagi na jego majątek, drugiego ubogim z powodu jego żądzy. Bogaty duchem nie zna namiętności, bogaty majątkiem nie zdoła nasycić chciwości. Przeto człowiek majętny, który za bogactwem wciąż goni, przyznaje się do swego ubóstwa”; tamże 6, 28, SAEMO 6, 152, PSP 35, 35: „Kimże jest człowiek bogaty, jeśli nie jaką́ nienasyconą otchłanią dla bogactw, niezaspokojonym pragnieniem czy też głodem złota. Im więcej pochłonie, tym bardziej rozpala się jego zachłanność".

${ }^{15}$ Por. tamże 3, 11, SAEMO 6, 138, PSP 35, 29: „Głęboko wierzycie, że jeśli tylko cokolwiek na świecie do innych należy, przynosi to wam szkodę. Czemuż to cieszą was gwałty zadane naturze? Świat został stworzony ku pożytkowi wszystkich ludzi, lecz mała grupa bogaczy pragnie go sobie przywłaszczyć"; zob. tamże 5, 21 i 25; tenże, De officiis ministrorum I 16, 62-63.

${ }^{16}$ Por. Ambrosius, De Nabuthae 6, 27, SAEMO 6, 150, PSP 35, 34-35: „Zasnęli snem swoim i nikt spośród nich nie znalazł żadnych bogactw w swych rękach. To znaczy nie znaleźli dobrych uczynków ci bogacze, którzy biednemu nic nie dali. Nikomu nie pomogli w potrzebie, żadnego uczynku dobrego nie zdołali odnaleźć ci, którzy kierowali się tylko swoją korzyścią". 
Również Augustyn z Hippony (354-430) ${ }^{17}$ wyprowadzał prawo własności dóbr materialnych ze stanowionego prawa ludzkiego, a nie z objawionego prawa Bożego, gdyż Bóg stworzył ludzi do relacji miłości oraz równych sobie praw co do godności, bez jakichkolwiek podziałów, także tych materialnych ${ }^{18}$; uznawał jednak własność prywatną, a potępiał poglądy tych, którzy ją odrzucają: manichejczyków ${ }^{19}$ oraz tzw. apostolików ${ }^{20}$. Biskup Hippony odrzucał także rygorystyczną pelagiańską interpretację rady ewangelicznej o dobrowolnym ubóstwie (Mt 19,21), którą to zachęte pelagianie traktowali jako ewangeliczny nakaz ${ }^{21}$. Dla Augustyna posiadanie dóbr materialnych nie było zatem czymś złym lub grzesznym, natomiast charakter człowieka okazywał się w sposobie używania dóbr materialnych: pokorny bogaty ufający Bogu jest lepszy niż pyszny ubogi ${ }^{22}$.

\section{PRZEZNACZENIE DÓBR MATERIALNYCH}

1. Uniwersalne przeznaczenie dóbr. Ambroży z Mediolanu najpełniej z Ojców Zachodnich wypowiedział się na temat powszechnego przeznaczenia dóbr materialnych. Podobnie, jak inni teolodzy okresu patrystycznego, także i Doktor z Mediolanu mówiąc o prawie powszechnego przeznaczenia dóbr, wyprowadzał je z biblijnej zasady głoszącej, że źródłem wszelkiego dobra jest Bóg ${ }^{23}$. Zasadę tę wspierał Ambroży ideami sprawiedliwości (iustitia) i braterstwa (fraternitas), które praktycznie sprowadzał do zasady solidarności i miłości wzajemnej wszystkich ludzi²4. Nawiązywał przy tym do idei stoickiej, według

${ }^{17}$ Szerzej na temat społeczno-ekonomicznych poglądów św. Augustyna z Hippony por. H.A. Deane, The political and social ideas of St. Augustine, New York 1963; W. Kornatowski, Społeczno-polityczna myśl świętego Augustyna, Warszawa 1965; A. Eckmann, Troska o ubogich w nauczaniu i dziatalności świętego Augustyna, VoxP 16 (1996) z. 30-31, 161-182; D. Burt, Friendship and society. An introduction to Augustine's practical philosophy, Michigan 1999; R.W. Dyson, The pilgrim city: social and political ideas in the writings of St. Augustine of Hippo, Woodbridge 2001; S. Jóźwiak, Państwo i Kościót w pismach św. Augustyna, Lublin 2004.

${ }^{18}$ Por. Augustinus, In Joannis Evangelium tractatus 6, 23, ed. A. Vita - E. Gandolfo - V. Tarulli, w: Nuova Biblioteca Agostiniana (=NBA), vol. 24/1, Milano - Roma 1985², 148, thum. W. Szołdrski: Homilie na Ewangelie i Pierwszy List św. Jana, PSP 15, Warszawa 1977, 110-111.

${ }^{19}$ Por. Augustinus, De moribus Ecclesiae catholicae et de moribus Manichaeorum I 34-35, NBA 13/1, Milano - Roma 1997, 62 i 64.

${ }^{20}$ Por. tenże, De haeresibus 40, NBA 12/1, ed. M. Falcioni, Milano - Roma 2003, 92.

${ }^{21}$ Augustinus, Epistolae 157, 23, NBA 22, ed. L. Carrozzi, Milano - Roma 1996², 614, tłum.P. Nehring, ŹM 27, Kraków 2002, 479-483 (przekład częściowy); zob. też pelagiański traktat anonimowego autora pt. De divitiis, PLS 1, 1380-1418.

${ }^{22}$ Por. Augustinus, Sermo 36, 5-7, NBA 29, 642; tenże, Ennaratio in Ps. 132, 4, ed. V. Tarulli, NBA 28/1, 310-312, tłum. J. Sulowski, PSP 42/1, Warszawa 1986, 105-106.

${ }^{23}$ Por. J. Bryja, Powszechne przeznaczenie dóbr w nauce Ojców i pisarzy kościelnych IV $i \mathrm{~V}$ wieku, Częstochowa 2002, 55-95.

${ }^{24}$ Por. Vasey, The social ideas in the works of. St. Ambrose, s. 225-235; R. Pankiewicz, Wstep, PSP 35, 11-16. 
której czymś godnym człowieka jest życie zgodne z naturą, co w konsekwencji prowadziło do tezy, że wszyscy ludzie są sobie równi. Kiedy jednak stoicy zalecali wzajemną pomoc i wspólnotę ze względu na głoszoną przez siebie ideę panteizmu, to Ambroży wskazywał na te same normy postępowania, wychodząc z zasady miłości ewangelicznej i z rozumnej natury człowieka ${ }^{25}$. Co więcej, kiedy sama natura przeznacza swe płody dla wszystkich ludzi, to właśnie z prawa natury wynika, że ziemia jest dla wszystkich ludzi dobrem powszechnym ${ }^{26}$.

Stosując wspomniany wcześniej podział dóbr ludzkich na dobra duszy, ciała i dobra zewnętrzne, Ambroży stwierdzał, że dzięki dobrom materialnym jak jedzenie, szaty i pieniądze człowiek nie odczuwa braków materialnych w życiu doczesnym ${ }^{27}$. Dobra zewnętrzne/materialne mają służyć człowiekowi, co wynika $z$ ich celowości jako rzeczy stworzonych ${ }^{28}$. Dobra materialne umożliwiają zatem człowiekowi życie codzienne, dlatego człowiek powinien z nich korzystać w sposób umiarkowany, unikając jednocześnie zbytku i zgubnych rozkoszy, gdyż w samych bogactwach (moralnie obojętnych) tkwi jednak możliwość grzechu ${ }^{29}$.

2. Umiarkowane i godziwe korzystanie z dóbr materialnych. Od traktatu Klemensa Aleksandryjskiego Który człowiek bogaty może być zbawiony istniała $\mathrm{w}$ chrześcijaństwie nieprzerwana tradycja umiarkowanego i godziwego korzystania z bogactwa. Myśl tę najkrócej można scharakteryzować następująco: z chrześcijańskiego punktu widzenia jest godziwym gromadzenie i korzystanie z dóbr materialnych, a ich godziwe używanie w życiu doczesnym nie wyklucza bogatego chrześcijanina z udziału w życiu wiecznym ${ }^{30}$.

Ambroży uznając prawo do własności prywatnej, podkreślał, że z prawa natury dobra materialne są przeznaczone dla całej ludzkości, ziemia jest niepodzielną własnością wszystkich ludzi, natura stworzyła prawo wspólnoty,

${ }^{25}$ Por. Pankiewicz, Wstep, PSP 35, 11-15; zob. Ambrosius, De Nabuthae 5, 19. 23. 25; 7, 32. $37 ; 8,40 ; 9,41 ; 10,45 ; 11,49 ; 13,56$.

${ }^{26}$ Por. Ambrosius, De Nabuthae 1, 2, SAEMO 6, 130-132, PSP 35, 26-27; tamże 3, 12, SAEMO 6, 138. 140, PSP 35, 26-27.

${ }^{27}$ Por. Ambrosius, Expositio Evangelii secundum Lucam 7, 245, ed. G. Coppa, SAEMO 12, Milano - Roma 1978, 276, thum. W. Szołdrski: Wykład Ewangelii wedtug św. Łukasza, PSP 16, Warszawa 1977, 348; zob. tenże, Hexaemeron VI 7, 42.

${ }^{28}$ Por. Ambrosius, De officiis III 3, 19, ed. G. Banterle, SAEMO 13, Milano - Roma 1977, 284, thum. K. Abgarowicz: Obowiqzki duchownych, Warszawa 1967, 170-171; zob. tenże, De excessu fratris sui Satyri 2, 55.

${ }^{29}$ Por. Ambrosius, De Spiritu Sancto III 17, ed. C. Moreschini, SAEMO 16, Milano - Roma 1979, 272-274; zob. Gulbinowicz, Etyczne poglady św. Ambrożego, s. 267.

${ }^{30}$ Por. Clemens Alexandrinus, Quis dives salvetur, tłum. J. Czuj: Czy człowiek bogaty może być zbawiony? , Warszawa 1953; Lindberg, Through a glass darkly, s. 37-52; Vasey, The social ideas in the works of. St. Ambrose, s. 156-164; McGuckin, The vine and the Elm Tree, s. 1-14; J.L. González, Faith and wealth: a history of early Christian ideas on the origin, significance, and use of money, San Francisco 1990. 
a prawo jednostki do posiadania powstało $\mathrm{z}$ uzurpacji jednostki ${ }^{31}$; dlatego też prywatne posiadanie nie jest sprzeczne z moralnością chrześcijańską. Prawo właściciela było jednak przez Ambrożego ograniczone do pokrycia potrzeb koniecznych. Wszystko to, co człowiek wydaje ponad potrzeby konieczne, stanowi zbytek i odbieranie pożywienia innym ${ }^{32}$. Człowiek bogaty powinien zatem pomagać ubogim z nadmiaru swych bogactw, wspierać sieroty, praktykować cnotę gościnności wobec przybyszów oraz pomagać chorym ${ }^{33}$. Ambroży jako jeden z pierwszych autorów chrześcijańskich określił też pojęcie godziwej moralnie ceny: wyznacza ją nie pożytek właściciela, ale uczciwość, która ma górować nad korzyścią ${ }^{34}$.

Augustyn z Hippony również propagował zasadę godziwego moralnie korzystania z dóbr materialnych: właściwym ich wykorzystaniem jest zatem ich używanie na pokrycie swych potrzeb i dzielenie się ich nadwyżką z ubogimi, gdyż to, co jest zbyteczne dla bogatego, jest konieczne dla ubogiego ${ }^{35}$. Człowiek w doczesności jest zależny od dóbr materialnych, lecz w perspektywie ostatecznego sądu z uczynków winien wyrzekać się rzeczy zbędnych i hamujących jego postęp duchowy ${ }^{36}$. Dla Doktora z Hippony warunkiem legalności własności prywatnej, jest właściwe, czyli zgodne z zasadami moralnymi, posiadanie dóbr materialnych ${ }^{37}$. Dzielenie się nadwyżką dóbr z potrzebującymi jest też dla Augustyna czynem wynikającym ze sprawiedliwości ${ }^{38}$. Dobra materialne są dla niego dobrami prostymi, nie nazywa ich jeszcze neutralnymi czy obojętnymi moralnie ${ }^{39}$. Dobra materialne mogą stać się złymi lub dobrymi przez ich zastosowanie: złymi czyni je złe używanie, zastosowane w dobrym celu są dobre ${ }^{40}$. Przez złe, czyli niemoralne używanie własności, zły właściciel

${ }^{31}$ Por. Ambrosius, De officiis I 28, 132, SAEMO 13, 102-104, thum. Abgarowicz, s. 66: „Z natury więc wywodzi się prawo wspólnej dla wszystkich własności. Prawo własności prywatnej jest wynikiem ludzkich uroszczeń"; zob. De Nabuthae 12, 53; Gulbinowicz, Etyczne poglady św. Ambrożego, s. 269.

${ }^{32}$ Por. Cz. Strzeszewski, Własność. Zagadnienia społeczno-moralne, Warszawa 1981, 117-118 (Własność w nauce patrystycznej: św. Ambroży).

${ }^{33}$ Por. Ambrosius, De Nabuthae 13, 57, SAEMO 6, 176-178, PSP 35, 46-47.

${ }^{34}$ Por. tenże, De officiis III 6, 37, SAEMO 16, 296, Thum Abgarowicz, s. 177: „Pożytek nie powinien górować nad uczciwością, lecz uczciwość nad korzyścią; mam na myśli pożytek w zwykłym pojęciu. Trzeba zabić w sobie chciwość, pozbyć się usilnego pragnienia zysku. Mąż świątobliwy wyznaje, że dlatego nie zajął się handlem, ponieważ czyhanie na podwyżkę cen nie jest sprawą uczciwości, lecz chytrości. Inny znowu tak mówi: Kto łakomi się na wysokie ceny zboża, przeklnie go lud".

${ }^{35}$ Por. Augustinus, Ennaratio in Ps. 147, 12-13, NBA 18/2, 824-828, PSP 42/1, 348-350.

${ }^{36}$ Por. tenże, Sermo 110, NBA 30/2, 365-372.

${ }^{37}$ Por. tenże, Contra Adimantum Manichaei discipulum 18, 1 - 19, 2, NBA 13/2, Roma 2000, 198-204, thum. J. Sulowski, PSP 54, 194-197.

${ }_{38}$ Por. tenże, Sermo 61, 3, NBA 30/1, 232; tenże, Ennaratio in Ps. 147, 12, NBA 18/2, 824.

${ }^{39}$ Por. D.J. Macqueen, St. Augustine's concept of property ownership, RechAug 8 (1972) 187-229.

${ }^{40}$ Por. Augustinus, Sermo 72, 4-5, NBA 30/1, 460-462; zob. tenże, Sermones 48, 8; 61, 3; 311, 9. 
traci prawo własności ${ }^{41}$. „Przyczyną złego korzystania z własności jest zatracenie przez właściciela właściwej hierarchii celów życia. Błąd ten określa św. Augustyn lapidarnie: frui utendis - szukanie celu w tym, co jest tylko środkiem dla celów wyższych"42.

3. Jałmużna. W obliczu tego, co możemy socjologicznie nazwać coraz większym rozwarstwieniem społeczeństwa rzymskiego, pod koniec IV wieku odnotowujemy w źródłach pisanych stałe nawoływanie do udzielania jałmużny potrzebującym, do której praktykowania zachęcali zarówno biskupi, jak i mnisi czy chrześcijanie świeccy ${ }^{43}$. Ambroży z Mediolanu czasami nawoływał wręcz do sprzedaży swoich dóbr i do postawy miłosierdzia wobec potrzebujących $^{44}$. Jak sugeruje R. Pankiewicz, nie da się tutaj wykluczyć wpływu na Ambrożego cynizujących stoików i cynicko-stoickiej ascezy Epikteta, pogardzającego bogactwem i bogaczami ${ }^{45}$. Stoicki wpływ na poglądy społeczne Biskupa Mediolanu można też dostrzec w wywodzeniu przez niego źródłosłowu łacińskiego pojęcia humanitas: nie od słowa homo, lecz od humus, czyli od naśladowania ziemi, która będąc matką rodzicielką, zawsze jest miłosierna dla ludzi za życia, jak i po ich śmierci. Stąd miłosierdzie (misericordia) staje się podstawą dobroczynności (beneficentia) ${ }^{46}$. Niezaprzeczalny wpływ na ideę jałmużny u Ambrożego odgrywało jednak przede wszystkim przesłanie Ewangelii: doskonały miłosierny powinien pomagać każdemu potrzebującemu ze swoich dóbr w zakresie koniecznym ${ }^{47}$. Potrzeba udzielania jałmużny wypływała u niego także z zasady obrony ludzi ubogich i słabych przed potęgą możnych. $\mathrm{Z}$ tego to powodu Biskup Mediolanu atakował wszelkie nadużycia i wyzysk - jako narzędzia ucisku ekonomicznego. Jałmużna, jego zdaniem, powinna być nie tyle prywatnym wspomaganiem ubogiego, ile ma posiadać charakter działalności społecznej, która łagodziłaby istniejące dysproporcje ekonomiczne w społeczeństwie rzymskim ${ }^{48}$.

Jałmużna chrześcijańska powinna być pomocą bezpośrednią a nie pośrednią; nie może też być skierowana do ludzi; którzy jej nie potrzebują, ale winna

\footnotetext{
${ }^{41}$ Por. Strzeszewski, Własność, s. 119; Augustinus, Epistola 153.

${ }^{42}$ Strzeszewski, Własność, s. 120; por. Augustinus, De diversis quaestionibus octoginta tribus 30.

${ }^{43}$ Por. R. Finn, Almsgiving in the later Roman Empire: Christian promotion and practice (313450), Oxford - New York 2006, 34-115.

${ }^{44}$ Por. Ambrosius, De Nabuthae 14, 58, SAEMO 6, 178, PSP 35, 47; tenże, De officiis I 11, 39; I 30, 149; II 21, 109.

${ }^{45}$ Por. Pankiewicz, Wstęp, PSP 35, 19-20.

${ }^{46}$ Por. tamże, s. 23-24.

${ }^{47}$ Por. Ambrosius, De Nabuthae 14, 58, SAEMO 6, 178, PSP 35, 47.

${ }^{48}$ Por. tamże 7, 33 i 36-37, SAEMO 6, 154 i156-158, PSP 35, 36 i 37-38; tamże 8, 40, SAEMO 6, 160-162, PSP 35, 39-40; tamże 9, 41 - 10, 45, SAEMO 6, 162 i 164-166, PSP 35, 40-41; tamże 12, 52-53, SAEMO 6, 170-172, PSP 35, 44-45; tamże 14, 59-60, SAEMO 6, 178-180, PSP 35, 47-48; tamże 15, 63, SAEMO 6, 182-184, PSP 35, 49-50.
} 
docierać wyłącznie do tych, którzy naprawdę potrzebują materialnego wspar$\mathrm{cia}^{49}$. Co do cnót moralnych, jakie winny kierować człowiekiem przy dawaniu jałmużny, Ambroży zaleca kierowanie się hojnością, radością i pokorą ${ }^{50}$. Biedny nie może odczuć poniżenia $\mathrm{z}$ faktu otrzymania od bogatego jałmużny ${ }^{51}$. Osobie bowiem dającej jałmużnę przynosi ona zysk duchowy, gdyż procenty z takiej pożyczki danej ubogiemu na ziemi, wypłaci Bóg na Sądzie Ostatecznym ${ }^{52}$. Ambroży zalecał też realistycznie, aby jałmużny nie dawać oszustom, czy też $z$ chęci wywyższenia się. Jałmużny nie należy również dawać osobom obcym, jeśli miałoby to dotknąć najbliższych, również znajdujących się w potrzebie ${ }^{53}$.

Także Augustyn z Hippony wzywał bogatych chrześcijan do dawania jałmużny ${ }^{54}$. Zgodnie z tym patrystycznym toposem ${ }^{55}$ Doktor z Hippony uzasadniał ofiarowanie jałmużny biednym prawdą wiary, mówiąca, że jedynym właścicielem dóbr jest tylko Bóg, a nie człowiek, oraz potrzebą sprawiedliwości społecznej ${ }^{56}$. Zachęcając wiernych do dawania jałmużny Augustyn zaznaczał kaznodziejsko, że dobra tak naprawdę przynależą do tych, którzy używają ich właściwie, czyli w tym wypadku do tych którzy dają jałmużnę, natomiast nie przynależą do tych, którzy tego nie czynią̨ ${ }^{57}$. Zachęcał też do rozsądnego dawania jałmużny: należy udzielać jałmużny w uzasadnionej potrzebie bliźniego z własnych dóbr, natomiast nikt nie powinien sam stać się biednym poprzez nierozsądne dawanie jałmużny; nie należy też wydać wszystkiego, czy prawie wszystkiego, ze swego majątku, by zaraz potem wyjść na ulice miasta i samemu prosić o jałmużnę ${ }^{58}$.

\section{KRYTYKA ZŁEGO UŻYWANIA DÓBR MATERIALNYCH}

Potępianie wady chciwości i praktyki lichwy w starożytności chrześcijańskiej było wyrazem zasad moralnych wynikających z nauki Objawionej

\footnotetext{
${ }^{49}$ Por. tenże, De officiis I 30, 143, SAEMO 13, 110, thum. Abgarowicz, s. 70.

${ }^{50}$ Por. tenże, De Nabuthae 8, 40, SAEMO 6, 160-162, PSP 35, 39-40; Gulbinowicz, Etyczne poglady św. Ambrożego, s. 279.

${ }^{51}$ Por. Ambrosius, De Nabuthae 13, 54, SAEMO 6, 174, PSP 35, 45.

${ }^{52}$ Por. tenże, De Nabuthae 14, 58-60, SAEMO 6, 178-180, PSP 47-48; tamże 16, 66-67, SAEMO 6, 188-190, PSP 51-52.

${ }^{53}$ Por. tenże, De officiis I 11, 38, SAEMO 13, 44, thum. Abgarowicz, s. 32; tamże I 25, 120 , SAEMO 13, 96, tłum. Abgarowicz, s. 61; tamże I 30, 147, SAEMO 13, 112, tłum. Abgarowicz, s. 71; tamże I 30, 150, SAEMO 13, 114, thum. Abgarowicz, s. 72-73.

${ }^{54}$ Por. A. Fitzgerald, Almsgiving in the works of Saint Augustine, w: Signum pietatis. Festgabe für Cornelius Petrus Mayer zum 60. Geburtstag, hrsg. A. Zumkeller, Würzburg 1989, 445-459.

${ }^{55}$ Por. Finn, Almsgiving in the later Roman Empire, s. 176-220.

${ }^{56}$ Por. Augustinus, Enarratio in Ps. 95, 15, NBA 27/1, 354-358, PSP 40, 277-279; tenże, Sermo 103, 5, 6, NBA 30/2, 266.

${ }^{57}$ Por. tenże, Sermo 50, 4, NBA 29, 948.

${ }^{58}$ Por. tenże, Epistola 243, 12, NBA 23, 832; tenże, Epistola 262, 5-6, 8, NBA 23, 910-912, 914.
} 
Starego i Nowego Testamentu ${ }^{59}$. Wypracowane z czasem nauczanie kościelne dotyczące lichwy, nie przyjmowało w tym wypadku norm ustawodawstwa rzymskiego odnośnie pobierania podatku od pożyczek (np. maksymalnej stopy procentowej). Najstarsze synody i normy kanoniczne bezwzględnie zakazywały lichwy, jak m.in. synod w Elwirze (ok. 303), synod w Arles (314), kanon 14 Soboru Nicejskiego (325), czy synod w Kartaginie (355). Ojcowie Kościoła IV i V wieku poruszając tematykę lichwy ustosunkowywali się do niej z religijnego i społeczno-moralnego punktu widzenia ${ }^{60}$.

1. Krytyka chciwości. Samo pragnienie złota jako wartości jest zwodnicze, bo opiera się tylko na ludzkiej umowie określającej złoto jako wartośćc1. Dlatego też Ambroży potępiał wszelkie przejawy chciwości, która jest zarówno bałwochwalstwem, jak i sprzeciwem wobec woli Stwórcy o powszechnym przeznaczeniu dóbr dla wszystkich ludzi ${ }^{62}$. Chciwość była też postrzegana przez niego jako choroba społeczna, gdyż niszczy zarówno samego bogacza ${ }^{63}$, jak i ludzi wokół niego ${ }^{64}$. Krytyka chciwości znajdowała u Ambrożego uzasadnienie w biblijnej tezie, mówiącej, że świat został stworzony dla wszystkich ludzi, którzy są braćmi. Wszyscy, tak bogaci, jak biedni, rodzą się i umierają bez jakiejkolwiek własności, pozbawieni nawet odzienia (Iz 5, 8; Hi 1, 21; Dz 8, 20) ${ }^{65}$ : dobra materialne są zatem dla wszystkich ludzi. Zagarnianie przez bogatych większości dóbr i niejako pozbawianie przez to możliwości

\footnotetext{
${ }^{59}$ Por. R. Newhauser, The early history of greed: the sin of avarice in early medieval thought and literature, Cambridge - New York 2000, 1-21.

${ }^{60}$ Por. J. Majka, Stanowisko chrześcijaństwa wobec lichwy w starożytności $i$ wczesnym średniowieczu, RTK 10 (1963) z. 2, 78-85.

${ }^{61}$ Por. Ambrosius, De Nabuthae 13, 55, SAEMO 6, 174, PSP 35, 45: „Dziwię się wam jednak, ludzie bogaci, dlaczego z takim uporem szukacie złota, kiedy jego siła jedyna opiera się prędzej na złudnym wrażeniu niż dużej wartości. «Złoto jest bowiem drzewem grzechu, a biada tym, którzy za nim gonią» (por. Syr 31, 7).

${ }^{62}$ Por. tamże De Nabuthae 3, 11, SAEMO 6, 138, PSP 35, 35: „Głęboko wierzycie, że jeśli tylko cokolwiek na świecie do innych należy, przynosi to wam szkodę. Czemuż to cieszą was gwałty zadane naturze? Świat został stworzony ku pożytkowi wszystkich ludzi, lecz mała grupa bogaczy pragnie go sobie przywłaszczyć. I to nie tylko prawo do posiadania ziemi, ale także samego nieba, powietrza i wody"; por. Vasey, The social ideas in the works of. St. Ambrose, s. 176-181.

${ }^{63}$ Por. tamże 6, 29, SAEMO 6, 152, PSP 35, 35: „«Miły jest sen niewolnika niezależnie od tego, czy zjadł dużo czy mało, a bogatemu nie dozwala zasnąć jego majątek» (por. Koh 5, 11). Podnieca go żądza posiadania, dręczy pokusa, by przywłaszczyć cudzą własność, szarpie zazdrość, popycha do czynu każda napotkana przeszkoda, niepokoi brak urodzaju, zakłóca spokój jego nadmiar”.

${ }^{64}$ Por. tamże 7, 35, SAEMO 6, 156, PSP 35, 37: „Chciwy zawsze ginie z nadmiaru plonów, gdyż wyczekuje małych zbiorów. Urodzaj zawsze służy wszystkim ludziom, niskie plony przynoszą zyski jedynie skąpcowi. Większą radością są dla niego wysokie ceny niż duże plony. I woli sam je posiadać, niż sprzedawać innym. [...] Tylko dla siebie domaga się płodów ziemi, i to nie w tym celu, by sam z nich korzystał, lecz aby innych pozbawić do nich dostępu".

${ }^{65}$ Por. tamże, De Nabuthae 1, 2, SAEMO 6, 130-132, PSP 35, 26-27; tamże 3, 11-12, SAEMO 6, 138-140, PSP 35, 29-30; tamże, 13, 54, SAEMO 6, 174, PSP 35, 45.
} 
korzystania z nich przez biedniejszych, jest zdaniem Ambrożego sprzeczne $\mathrm{z}$ prawem natury ${ }^{66}$.

Sami bogacze bogacąc się stopniowo nie zaznają szczęścia, gdyż każda kolejna zdobycz wzmaga ich żądze następnych zdobyczy, a źródłem takiego bezustannego zdobywania jest chciwośćc ${ }^{67}$. Chciwcy paradoksalnie nie cieszą się z dochodu czy obfitych zbiorów, ale sztucznie lamentują, że zagraża im nędza, by usprawiedliwić nienasycone pragnienie posiadania ${ }^{68}$. Zachłanność bogactwa była, zdaniem Ambrożego, często podsycana przez innych chciwców, tj. chciwe kobiety bogaczy, których biblijnym symbolem staje się królowa Jezabel ${ }^{69}$. Chciwe kobiety przysparzają bogatym ciagłych wydatków, aby gonić jedynie za wygodą i kosztownościami ${ }^{70}$. Chciwość jest chorobą, niewolą i służbą grzecho-

${ }^{66}$ Por. tamże 1, 1, SAEMO 6, 130, PSP 35, 26: „Dawna opowieść o Nabocie odnosi się i do czasów obecnych. Bo któż dziś z ludzi bogatych nie pragnie zawładnąć cudzą własnością? Któż z możnych nie dąży usilnie do wyrzucenia ubogiego z niewielkiego skrawka jego ziemi i nie pragnie przy tym wypędzić go z ojcowizny? Komu wystarcza własna posiadłość? Kogo spośród możnych nie niepokoi widok leżącego w sąsiedztwie majątku? Przeto nie jeden tylko Achab pojawił się na świecie, lecz każdego dnia rodzi się ktoś jego rodzaju i zawsze istnieć będzie na tym świecie ten gatunek ludzi”.

${ }^{67}$ Por. tamże 12, 52, SAEMO 6, 170, PSP 35, 40: „To wy, ludzie bogaci, pozostajecie w służbie godnej pogardy, wy którzy służycie występkom, wy którzy służycie żądzy, wy którzy służycie chciwości, której nie sposób nasycić".

${ }^{68}$ Por. tamże 6, 31, SAEMO 6, 154, PSP 35, 36: „Co zrobię - powiada - jeśli nic nie mam”. Mówi bogaty do siebie: „Nic nie mam”. Te słowa toż czyste ubóstwo. Bogaty dzięki dobrym plonom rozmyśla o nędzy. [...]. Czyż wierzysz w to co mówi: Zbyt małe dochody, skąd wezmę na życie. Czyż nie jest szczęśliwy ten, komu zagraża urodzaj? Bardziej nieszczęśliwy jest tamten z uwagi na swoje bogactwo, aniżeli biedak, któremu zagraża nędza".

${ }^{69}$ Por. tamże 3, 13, SAEMO 6, 140, PSP 35, 30: „Do ciebie bogaczu należy to, o co zabiegasz, i jeśli byłbyś przezorny, to nie sprzedałbyś pola twego za noc z ulicznicą, nie wydałbyś swego majątku na hulanki i błyskotki, nie stałby się dom twój miejscem hazardu, nie porzuciłbyś odziedziczonego po przodkach skromnego stylu życia"; tamże 11, 49, SAEMO 6, 168, PSP 35, 43: „Unikaj zatem bogaczu takiego końca, a unikniesz podobnej śmierci, o ile ustrzeżesz się czynów występnych. Nie naśladuj Achaba, i nie pożądaj majątku w sąsiedztwie. Niechaj nie zamieszka z tobą Jezabel - żądza, niosąca ci zgubę - która mogłaby ciebie namówić do rozlewu krwi, i która nie gasiłaby twoich żądz, lecz je podsycała, która także powiększałaby twój smutek, gdy chciałbyś zagarnąc to, co zapragniesz, i dzięki której będąc bogatym stałbyś się nagim”.

${ }^{70}$ Por. tamże 5, 25-26, SAEMO 6, 148-150, PSP 35, 34: „Lecz by odwrócić zło od domu twego, musisz się zmienić wraz z żoną swoją. To ona zachęca, abyś odkupił, co już sprzedane. Co więcej, zachęca, byś świat na sposób kobiety odmienił, choć mógłbyś pomóc ludziom ubogim. To ona ci przysparza ciagłych wydatków, by sycić swe oczy widokiem klejnotu, by spać w purpurowej szacie i leżeć na srebrnej sofie. To ona cię zachęca, abyś w złoto uzbroił jej rękę, a szyje w kosztowny naszyjnik. Bo lubią być kobiety związane bransoletami, byleby tylko więzy były ze złota. Nie widzą, że żyją w długach, dopóty błyszczy coś w skarbcu na dnie. A tym się martwią, jak złoto do złota dołączyć i perły na szyi zawiesić. Mają ozdoby po kilka funtów ważące, a także posiadają stroje kosztowne, dziwacznie uszyte. Pocą się pod ciężarem ozdób i marzną w szatach z jedwabiu. Kochają bogactwa i ulegają wszelkim swoim zachciankom. [...]. Nawet wówczas, gdy ruina zagraża majątkowi, nie poniechają wydatku, dopóki nie zaspokoją swojej chciwości”. Krytyka chciwych kobiet przynależała już do pewnego toposu literackiego, por. Plutarchus, De 
wi. Chciwy nie zdoła uniknąć śmierci, choć przez jałmużnę mógłby zebrać plony w niebie i umknąć śmierci wiecznej. Stąd Ambroży zalecał rozdanie majątku ${ }^{71}$.

Augustyn, podobnie jak wcześniej Ambroży, potępiał chciwość dóbr materialnych, a szczególnie żądzę posiadania pieniędzy. Mówiąc o chciwości, nie chodziło mu o chciwość w sensie nieumiarkowanego pożądania jakiegokolwiek dobra (honoru, władzy, czy poznania), ale o chciwość dóbr materialnych. Chciwością było nazwane nieuporządkowane pragnienie dóbr, a szczególnie dóbr materialnych, utożsamianych ze złotem lub srebrem, czyli z pieniędzmi (etymologicznie: avaritia od aviditas auri, czyli żądza złota; podobnie grec.

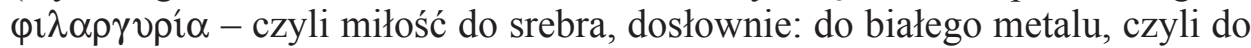
monet ze srebra, denarów) ${ }^{72}$. W konsekwencji chciwość pieniędzy dotyczyła wszystkich dóbr użytkowych, jakie można nabyć za pieniądze ${ }^{73}$. Przejawem chciwości był dla Doktora z Hippony wszelki zarobek ponad minimum środków potrzebnych do życia; odrzucał on także chęć gromadzenia pieniędzy oraz negował wszelkie cechy pozytywne, wiążące się ze zdobywaniem nadmiernego majątku: ideałem było dlań posiadanie dóbr zgodnie $\mathrm{z}$ umiarem ${ }^{74}$.

2. Krytyka lichwy. Ambroży z Mediolanu w traktacie $O$ Tobiaszu ${ }^{75}$, powstałym najprawdopodobniej między 385 a 389 r., zawarł ostrą krytykę bogaczy uprawiających lichwę, która była pod koniec IV wieku dotkliwą plagą społeczną ${ }^{76}$. Niewypłacalni dłużnicy sprzedawali swe dzieci, by uiścić długi, lub sami byli sprzedawani w niewolę przez lichwiarzy ${ }^{77}$, a ci posuwali się nawet do zatrzymywania zwłok zmarłych dłużników ,jako zastaw i odmawiali pogrzebania ciała, dopóki dług nie zostanie spłacony"78. Ambroży potępiał kapitał lichwiarski, gdyż widział w nim stale odradzającą się wartość, której nic i nikt nie jest w stanie zagrozić. Pieniądz będący bez przerwy w obrocie przy-

cupiditate divitiarum 5-6, thum. Z. Abramowiczówna: $O$ żązy bogactwa, w: Plutarch, Moralia (wybór), Biblioteka Klasyków Filozofii 123, Kraków 1977, 97-100; Vergilius, Georgica II 506, thum. Z. Abramowiczówna: Wergiliusz, Bukoliki i Georgiki, BN II 83, Wrocław 1953, 88.

${ }^{71}$ Por. Ambrosius, De Nabuthae 6, 27-29, SAEMO 6, 150-152, PSP 35, 34-35; tamże 7, 35-37, SAEMO 6, 156-158, PSP 35, 37-38; tamże 8, 38, SAEMO 6, 158-160, PSP 35, 38-39; tamże 13, 55-57, SAEMO 6, 174-176, PSP 35, 45-47; tamże 14, 58-60, SAEMO 6, 178-180, PSP 35, 47-48.

${ }^{72}$ Więcej na temat stosunku chrześcijan IV-V wieku do pieniądza, por. J. Jundziłł, Złoto i srebro jako pieniqdz $w$ literaturze patrystycznej okresu późnego Cesarstwa Rzymskiego, VoxP 7 (1987) z. 12-13, 189-203.

${ }^{73}$ Por. Augustinus, De Genesi ad litteram XI 15, 19-20, NBA 9/2, ed. L. Carrozzi, Roma 1989, 580, 600, thum. J. Sulowski, PSP 25, Warszawa 1980, 326-327.

${ }^{74}$ Por. J. Jundziłł, Pieniqdz w łacińskiej literaturze chrześcijańskiej okresu późnego cesarstwa, SACh 3, Warszawa 1984, 170, odnośnie augustyńskich określeń chciwości zob. szczególnie przypis 69.

${ }^{75}$ Por. Ambrosius, De Tobia, SAEMO 6, 198-285, thum. J. Jundziłł, PSP 35, Warszawa 1986, 80-121.

${ }^{76}$ Por. Vasey, The social ideas in the works of. St. Ambrose, s. 165-171; J. Jundziłł, Wstęp. Traktat Ambrożego o Tobiaszu, PSP 35, 57-79.

${ }^{77}$ Por. Ambrosius, De Tobia 8, 29-31, SAEMO 6, 224-226, PSP 35, 92-93.

${ }^{78}$ Tamże 10, 36, SAEMO 6, 230-232, PSP 35, 94. 
nosi zyski niezgodne z naturą, tak wielkie, że czasami zbrodnicze. Porównanie dochodów następowało u Ambrożego z zyskami z rolnictwa ${ }^{79}$. Jak zauważa J. Jundziłł, taka krytyka lichwy przedstawiana przez św. Ambrożego była częściowo nieobiektywna, ale jak najbardziej odpowiadająca arystokracie rzymskiemu, ceniącemu ziemię i stosującemu klasyczną już wtedy argumentację Arystotelesa o nieproduktywności pieniędzy ${ }^{80}$.

Krytyka lichwy u Biskupa Mediolanu ma przede wszystkim podłoże religijne: ganiąc wady ludzkie zwalczał on chciwość i w takim kontekście polemicznym wypowiadał się też na temat pieniędzy. Pieniądze z religijnego punktu widzenia nie są w stanie zapewnić zbawienia, a ich chciwość jest przeszkodą do zbawienia ${ }^{81}$. Praktyka lichwy została przez niego określona jako nienaturalna, gdyż opiera się na oszustwie w posługiwaniu się pieniądzem, choć nie potępiał on nigdy pożyczki, która ma na celu przede wszystkim sprawiedliwą pomoc bliźniemu ${ }^{82}$. Lichwa jest zakazana przez Prawo Starego Testamentu (Pwt 23, 19); krzywdę wyrządzaną ludziom przez lichwiarzy opłakiwał już król Dawid $^{83}$, z chęci zysku Judasz zdradził Chrystusa i sprzedał go Sanhedrynowi ${ }^{84}$. Natomiast Chrystus w Ewangelii (Łk 6, 32-36) zachęca do udzielania pożyczek tym, którzy nie mogą ich zwrócić, czyli do utraty zysku lichwiarskiego ${ }^{85}$.

${ }^{79}$ Por. tamże 13, 43, SAEMO 6, 238-240, PSP 35, 98-99: „Uważam, że wyraz usura (procent) pochodzi od usus - używanie, ponieważ jak przez używanie odzieży zużywa się ona, tak procenty niszczą ojcowiznę. [...]. Pieniądz lichwiarski dziś bywa zasiany - jutro już owocuje; zawsze zostaje zasadzony ponownie i nigdy nie odpoczywa. Lichwiarz chce ciagle zyskiwać, nigdy stracić. Uznaje zasadę, że nigdy nie należy przechowywać swych pieniędzy i zawsze utrzymuje je w obrocie. Dąży do tego, by nigdy nie uzdrawiać, a zawsze zabijać".

${ }^{80}$ J. Jundziłł (Wstęp. Traktat Ambrożego o Tobiaszu, s. 70 i 77) komentując powyższą kwestię podkreślał, że w IV wieku kapitał oprocentowano najczęściej w wysokości do 1/100 miesięcznie, czyli 12\% rocznie (górna granica, której wysokość stała się w Cesarstwie Rzymskim tamtego okresu powszechnie obowiązująca), co jest wysoką stopą procentową. Byłą ona usankcjonowana prawnie, choć byłą niższa od okresu wczesnego cesarstwa, kiedy żądano $36 \%$ rocznie.

${ }^{81}$ Por. Jundziłł, Pieniadz w tacińskiej literaturze chrześcijańskiej okresu późnego cesarstwa, s. 150-160, odnośnie określeń chciwości u Ambrożego por. szczególnie przypis 25, s. 151.

${ }^{82}$ Ambrosius, De Tobia 2, 7, SAEMO 6, 202, PSP 35, 83: „Gdy więc użyczył pieniędzy, ale nie dał na procent, dopełnił obowiązku przestrzegania sprawiedliwości. Złem jest bowiem zysk, którego szuka się przez procenty, lecz nie jest zła ta pożyczka, o której napisano: «Pożycz bliźniemu swemu, kiedy jest w potrzebie» $($ Syr 29, 2). [...]. Inna jest zaś ta pożyczka, zwyczaj bezecny, która polega na dawaniu pieniędzy na procent - czego Prawo zabrania (por. Pwt 23, 19). Lecz odrzucał to Tobiasz, który napominał syna, aby przykazania Pana nie naruszył, aby z majątku swego jałmużny udzielał, a nie pożyczał na procent".

${ }^{83}$ Por. tamże 4, 12, SAEMO 6, 208, PSP 35, 84.

${ }^{84}$ Por. tamże 4, 12, SAEMO 6, 208, PSP 35, 84-85: „Przeto, gdy miał głosić o zdradzie Judasza, zapowiedział, że ponad zazdrość świętokradczą właśnie zbrodnicza chęć zysku spowoduje spisek prowadzący do zabicia Pana, jak również, że tak wielkie świętokradztwo pomszczone będzie wystarczająco i obficie przez lichwiarski zysk. Źli to byli lichwiarze, którzy dali pieniądze, aby zabić sprawcę zbawienia, źli i ci, którzy dają by zabić niewinnego".

${ }^{85}$ Por. tamże 16, 54, SAEMO 6, 252, PSP 35, 104-105. 
Augustyn z Hippony również odrzucał lichwę z powodów religijnych. Lichwą zaś określał wszelkie pożyczki udzielane w celu osiagnięcia większych korzyści, niż wynosi wartość pożyczonej kwoty, czy oczekiwania darów w naturze w zamian za pożyczkę. Lichwa była dla niego praktyką zawsze naganną, gdyż lichwiarz osiąga korzyści bez pracy czy też ciagnie zyski od zysków, a są to oszustwa i niemoralność sprzeczna z prawem boskim i ludz$\mathrm{kim}^{86}$; postępowanie lichwiarza krzywdzi innych, w samym lichwiarzu wzbudza jedynie chciwość kolejnych dóbr i oddala go od Boga ${ }^{87}$.

\section{PELAGIAŃSKA KRYTYKA BOGACTW}

Odrębny pogląd na temat chrześcijańskiego sposobu posiadania dóbr materialnych posiadali heterodoksyjni pelagianie, potępieni za swoje poglądy najpierw na synodach Kościoła afrykańskiego w 411, 416 i 418 r. oraz decyzjami papieży - Innocentego I w 416 r. i Zozyma (po 1 maja 418 r.) ${ }^{88}$. Orzeczenia te potwierdziła 9 lipca 425 r. augusta Galla Placydia, wydając w imieniu małoletniego Walentyniana III reskrypt przeciwko pelagianom, przebywającym na terytorium Diecezji Galii i nakazując administracji imperialnej zdecydowaną walkę z nimi ${ }^{89}$. Ostatecznie w 431 r. na III Soborze Powszechnym w Efezie pelagianie zostali formalnie wyłączeni z Kościoła ${ }^{90}$.

Według twierdzeń pelagian człowiek zawsze posiada niczym nieograniczoną wolną wolę oraz osobistą moralną odpowiedzialność. Nauka mnicha Pelagiusza, rozwinięta doktrynalnie przez Celestiusza, a szczególnie przez biskupa Juliana z Eklanum k. Benewentu, akcentowała niemożliwość pogodzenia łaski Bożej i wolnej woli, śmiertelność pierwszego człowieka Adama oraz przyjmowała, że dzieci nieochrzczone osiagną zbawienie ${ }^{91}$. Pelagianie odrzucali augustyńskie rozumienie grzechu pierwszych ludzi, który, ich zdaniem, był pierwszym złym

${ }^{86}$ Por. Augustinus, Enarratio in Ps. 36, 3-5, NBA 25, 750-754, PSP 38, 28-29; tenże, Enarratio in Ps. 128, 6, NBA 28/1, 172, PSP 42/1, 56-57; tenże, Epistola 153, 6, 25-26, NBA 22, 552-554.

${ }^{87}$ Por. Jundziłł, Pieniadz $w$ tacińskiej literaturze chrześcijańskiej, s. 171-172, na temat augustyńskich definicji lichwy zobacz szczególnie przypis 71, s. 171.

${ }^{88}$ Por. K. Burczak, Biskupi afrykańscy wobec herezji pelagianizmu, VoxP 22 (2002) t. 42-43, 437-455.

${ }^{89}$ Por. Marius Mercator, De synodis habitis in causa Pelagianorum (XXI Synodus), PL 48, 369B.

${ }^{90}$ Por. Epistula synodalis (22 VII 431) can. 1 i 4, Mansi V 1338 lub ŹMT 24 (= DSP 1), 162 164; zob. G. Bonner, Pelagius / Pelagianischer Streit, w: TRE 26, hrsg. G. Müller, Berlin - New York 1996, 178-185.

${ }^{91}$ Więcej na temat teologii i kontrowersji pelagiańskiej por. V. Grossi, La polemica pelagiana: avversari e amici di Agostino, w: Patrologia, , ed. A. di Berardino, vol. III: Dal Concilio di Nicea (325) al Concilio di Calcedonia (451). I Padri latini, Casale 1978, 437-465; J.P. Burns, The interpretation of Romans in the Pelagian controversy, AugSt 10 (1979) 43-54; A. Baron, Pelagiusz i jego dzieło, w: Pelagiusz, Komentarz do Listu św. Pawła do Rzymian, ŹMT 15, Kraków 1999, 12-167; H. Krabbendam, Sovereignty and responsibility: the Pelagian-Augustinian controversy in philosophical and global perspective, Bonn 2002; M. Lamberigts, Recent research into Pelagianism with particular emphasis on the role of Julian of Aeclanum, „Augustiniana” 52 (2002) 175-198. 
przykładem, nie niszczącym jednak natury ludzkiej, dlatego też inni ludzie nawet po grzechu Adama i Ewy posiadali wolną wolę. Dla Pelagiusza usprawiedliwienie człowieka jest niezasłużonym darem Chrystusa, który odkupił ludzkość przez ofiarę swej Krwi i potwierdził to w sakramencie chrztu ${ }^{92}$. Jednak odkupienie stanie się dla ludzi owocne, kiedy przestaną oni grzeszyć, stąd pelagianie zachęcali do prowadzenia ściśle ascetycznego sposobu życia i popierali konieczność istnienia Kościoła dla ascetyczno-moralnej elity ${ }^{93}$.

Zdaniem A. Solignaca, potępienie bogactw materialnych stanowiło jeden z głównych postulatów ruchu pelagiańskiego; nawet jeśli w pismach samego Pelagiusza nie znajdujemy na ten temat wielu uwag ${ }^{94}$, to potępienie bogactw mieściło się w nie spisanym nauczaniu Pelagiusza ${ }^{95}$ oraz traktatach pozostałych pelagian, np. Fastydiusza (Homilia de poenitentibus, Epistula ad Pammachium et Oceanum de renuntiatione saeculi), Pseudo-Sykstusa (Epistula «Honorificantiae»), w anonimowych dziełach pelagiańskich (np. Epistula «Humanae»), czy wreszcie Tractatus de divitiis ${ }^{96}$. Wydaje się natomiast na podstawie zachowanych pism, że sam Pelagiusz zdecydowanie odrzucał wadę chciwości, a kwestię posiadania dóbr materialnych łączył przede wszystkim z dobroczynnością i rozdawaniem dóbr ${ }^{97}$.

Odnośnie kwestii bogactwa i ubóstwa bardzo znaczącym dla ruchu pelagiańskiego był anonimowy ${ }^{98}$ traktat De divitiis ${ }^{99}$. Autor tego dziełka dzielił dobra materialne na: bogactwo (tzn. mieć więcej, niż to co konieczne), ubóstwo (tzn. aby brakowało tego, co wystarczające), oraz wystarczające (nie posiadanie więcej, niż to co konieczne) ${ }^{100}$. W duchu skrajnie ascetycznej interpretacji przykładu życia Jezusa Chrystusa - jako absolutnie ubogiego materialnie, pelagiański autor De divitiis odrzucał bogactwo materialne i proponował ciągłe szukanie równości majątkowej dla naśladowców Chrystusa ${ }^{101}$. Sposób zdobywania i kumulacji bogactwa wynikał dla autora De divitiis z nierówności spo-

${ }_{92}$ Por. M. Michalski, Nauka chrystologiczna Pelagiusza, CT 17 (1936) 143-164, szczególnie s. 155; E. Florkowski, Soteriologia Pelagiusza, Kraków 1949, 103-150.

${ }^{93}$ Por. Baron, Pelagiusz i jego dzieło, s. 106-116.

${ }^{94}$ Por. Pelagius, Epistola ad Marcellam 8, PL 30, 54: „Tolerandae sunt [...] depositis oneribus et impedimentis atque compedibus, quibus saeculi huius divites attinentur, tu iam liberata et expedita".

${ }^{95}$ Por. Augustinus, De gestis Pelagii 35, 65, ed. A. Trapè - I. Volpi, NBA 17/2, Roma 1981, 116-118, tłum. K. Obrycki, ŹMT 12, Kraków 1999, 270: „Jeśli bogaci chrześcijanie nie wyrzekną się wszystkiego, nie posiądą królestwa Bożego i nic nie zostanie im uznane, nawet gdyby sądzili, że coś dobrego uczynili".

${ }^{96}$ Por. A. Solignac, Pélage et pélagianisme, DSp 2923-2936, spec. 2933.

${ }^{97}$ Por. Baron, Pelagiusz i jego dzieło, s. 112-115.

${ }^{98}$ G. Bonner (Augustine and modern research on Pelagianism, Villanova 1972, 7-8), zasugerował, że autorem pelagiańskiego traktatu De divitiis jest prawdopodobnie tzw. anonyme sicilien.

${ }^{99}$ Por. Anonymus, De divitiis, PLS 1, 1380-1418; zob. S. Toscano, Tolle divitem. Etica, società e potere del «De divitiis», Catania 2006.

${ }^{100}$ Por. De divitiis 5, 1, PLS 1, 1383.

${ }^{101}$ Por. tamże 6, 3, PLS 1, 1386-1387. 
łecznej i wyzysku biednych przez bogatych ${ }^{102}$. Wychodząc $z$ podstawowego pelagiańskiego założenia, że zbawienie człowiek może sam sobie wysłużyć przez swe praktyki ascetyczne, autor De divitiis w kluczu negacji i wyrzeczenia się bogactwa zinterpretował wybrane teksty Nowego Testamentu (Mt 8, 20; 19,21 ; Łk 14, 33; 1Kor 7, 7; 11, 21) i wysunął ostateczny wniosek całkowitego wyrzeczenia się przez chrześcijan dóbr materialnych, jako rozwiązania właściwie duchowego $\mathrm{i}$ jedynie zgodnego $\mathrm{z}$ nauczaniem ewangelicznym ${ }^{103}$.

Odpowiedzią na powyższe tezy pelagiańskie był List 157 Augustyna z Hippony, skierowany do Hilarego, biskupa Syrakuz, gdzie działała liczna grupa pelagian, i prawdopodobnie także pelagiański autor De divitiis. Biskup Hippony interpretując Łk 18, 25, stwierdził, że zarówno chrześcijańskie wyrzeczenie się bogactw, jak i sprawiedliwe, dobre i miłosierne używanie bogactw, jest darem łaski, i nikt nie może się chlubić własnymi uczynkami, ale winien uzać pierwszorzędną rolę łaski Bożej w dziele wysługiwania zbawienia ${ }^{104}$. Augustyn przypomniał także, że również w tekstach św. Pawła spotyka się przede wszystkim zalecenie właściwego używania bogactwa ${ }^{105}$, natomiast zarówno Chrystus, jak i św. Paweł, który jest nauczycielem tej samej Chrystusowej doktryny, nigdzie nie nakazują chrześcijanom obowiązku wyrzeczenia się wszelkich dóbr materialnych, ale właściwego używania bogactw, a przede wszystkim nie wpadania w pychę ${ }^{106}$. Chrześcijanin powinien zatem przedkładać Chrystusa ponad wszelką inną wartość ${ }^{107}$, może posiadać dobra, ale zdobyte w sposób uczciwy i zarządzać nimi moralnie godziwie ${ }^{108}$, nigdy nie gromadzić bogactw w sposób niesprawiedliwy ${ }^{109}$, wyrzekać się dóbr niepotrzebnych i dzielić dobrami zbywającymi z potrzebującymi ${ }^{110}$, gdyż niebo odziedziczą także bogaci bojący się Boga ${ }^{111}$.

\section{MONASTYCZNA KRYTYKA BOGACTW}

To, co obecnie w Kościele katolickim określamy jako ślub ubóstwa ze względów religijnych, odpowiadało we wczesnochrześcijańskim monastycyzmie całemu szeregowi praktyk, które nie mogą być sprowadzone do jed-

${ }^{102}$ Por. tamże 7, 5, PLS 1, 1388; tamże 8, 1, PLS 1, 1388.

${ }^{103}$ Por. tamże 9-10, PLS 1, 1390-1397.

${ }^{104}$ Por. Augustinus, Epistola 157, 4, 29, NBA 22, 620-622.

${ }^{105}$ Por. 1Tm 6, 17-19: „Bogatym na tym świecie nakazuj, by nie byli wyniośli, nie pokładali nadziei w niepewności bogactwa, lecz w Bogu, który nam wszystkiego obficie udziela do używania, niech czynią dobrze, bogacą się w dobre czyny, niech będą hojni, uspołecznieni, odkładając do skarbca dla siebie samych dobrą podstawę na przyszłość, aby osiągnęli prawdziwe życie”.

${ }^{106}$ Por. Augustinus, Epistola 157, 4, 26-27, NBA 22, 618-620.

${ }^{107}$ Por. tamże 157, 4, 33, NBA 22, 626; zob. 1Tm 6, 17; 1Kor 7, 30-31.

${ }^{108}$ Por. tamże 157, 4, 32-33, NBA 22, 624-626.

${ }^{109}$ Por. tamże 157, 4, 37, NBA 22, 630; zob. Łk 16, 9.

${ }^{110}$ Por. tamże 157, 4, 34, NBA 22, 626-628.

${ }^{111}$ Por. tamże 157, 4, 37, NBA 22, 630. 
nego oficjalnego ślubu mniszego. Formalne wprowadzenie klasycznych dla chrześcijaństwa zachodniego trzech ślubów zakonnych (posłuszeństwa, czystości i ubóstwa), miało miejsce po raz pierwszy dopiero w Regule Zakonu Trójcy Przenajświętszej (trynitarzy) w 1198 roku $^{112}$. Natomiast pierwsi mnisi chrześcijańscy w Kościele Zachodnim (IV w.), podobnie jak wcześniej mnisi w Kościele Wschodnim (III/IV w.), praktykując cnotę ubóstwa nigdy nie separowali jej od innych cnót i praktyk życia monastycznego: oddzielenia od świata doczesnego, wyrzeczenia się rodziny, posłuszeństwa przełożonemu monastycznemu, modlitwy, postu, i wielu innych, które wszystkie razem formowały styl monastycznego conversatio ${ }^{113}$.

W latach 30-tych IV wieku został przełożony na łacinę Żywot św. Antoniego ${ }^{114}$, który zaoferował monastycyzmowi zachodniemu model mnicha, który wyrzekł się swoich doczesnych dóbr ziemskich (oddziedziczonych po rodzicach $)^{115}$, rozpoczął życie monastyczne, a oddając się własnoręcznej pracy zarabiał w ten sposób na życie i na możliwość dawania jałmużny z własnych dochodów ${ }^{116}$. Wraz z propagacją w Kościele Zachodnim eremickiego modelu monastycyzmu w wydaniu Antoniego pustelnika, zapoczątkował swoją kampanię przeciwko pieniądzu i posiadaniu dóbr materialnych św. Hieronim ze Strydonu w Dalmacji117. Tym samym rozpoczęła się polemika mnichów zachodnich, skierowana przeciwko wadzie chciwości, i ukształtował się model cenobity, wychwalanego przez autorów ascetycznych za to, że oddaje swoim przełożonym monastycznym swój dzienny zarobek, a otrzymuje od nich

${ }^{112}$ Por. Regula sancti Joannes de Matha ab Innocentio papa III aprobata 1, 1, w: Regola e Costituzioni dei Frati dell'Ordine della SS.ma Trinità, Roma 1986, 10: „Fratres domus Sancte Trinitatis sub obedientia prelati domus suae, qui minister vocabitur, in castitate et sine proprio vivant"; więcej na temat dość powolnego kształtowania się idei trzech ślubów zakonnych zob. M.J. Sedano Sierra, Voti religiosi, I: Storia, w: A.A. Rodríguez - J.M. Casas, Dizionario teologio della vita consacrata, ed. italiana, Milano 1994, 1923-1936; J. Gribomont, Voto, I: In Oriente, DIP X 550-553; G. Rocca, Voto, II: In Occidente: visione storico-giuridica generale del voto solenne e del voto semplice, DIP X 553-564.

${ }^{113}$ Por. A. De Vogüé, Povertà, III. In Occidente: monachesimo e vita canonicale dalle origini al sec. XI, DIP VII 261.

${ }^{114}$ Por. Athanasius Alexandrinus, Vita s. Antonii, PG 26, 835-976, tłum. E. Dąbrowska: Żywot św. Antoniego, ŹM 35, Kraków 2005, 77-152.

${ }^{115}$ Por. tamże 1-3, PG 26, 839-845, ŹM 35, 78-80.

${ }^{116}$ Por. tamże 3, PG 26, 844-845, ŹM 35, 80: „Utrzymywał się z pracy rąk, ponieważ słyszał: Kto nie chce pracować, niech też nie je. Z tego, co otrzymywał, część zostawiał na chleb, część zaś przeznaczał dla potrzebujących. Modlił się ciągle, ponieważ dowiedział się, że modlić się należy nieustanne. A z taką uwagą słuchał, gdy czytano Pismo, żeby nic z niego nie padło na ziemię, że pamięć wystarczała mu za książki”"

${ }^{117}$ Por. Hieronymus, Epistola 14, 6, PL 22, 351, przekład własny: „Doskonały uczeń Chrystusa poza Chrystusem nie posiada na własność niczego"; Epistola 125, 20, PL 22, 1085, przekład własny: „Naśladować nagiego Chrystusa nagim”; szerzej na temat stopniowego odrzucania dóbr materialnych i coraz bardziej negatywnego podejścia do posiadania przez ascetów i mnichów zachodnich zob. Newhauser, The early history of greed, s. 22-95. 
bez specjalnego proszenia tylko ściśle konieczne minimum dóbr, z którego ma być zadowolony ${ }^{1}$. Augustyn z Hippony wprowadził dla zachodnich mnichów najpierw zasadę ascetyczną: ,nikt nie posiada niczego na własność, nikt nie jest ciężarem dla drugiego"2, a następnie w swoich pismach monastycznych odmówił mnichom posiadania czegokolwiek na własność ${ }^{3}$, wskazując na ideał wspólnoty myśli i uczuć w pierwotnej gminie jerozolimskiej. Rufin z Akwilei thumacząc monastyczne dzieła Bazylego Wielkiego Asceticon (Instituta monachorum) oraz Regułe bazyliańską, zwrócił uwagę mnichów zachodnich zarówno na ideał indywidualnego wyrzeczenia się samego siebie, swoich namiętności i dóbr ${ }^{5}$, jak i na ideał życia wspólnego, w tym wspólnoty dóbr materialnych oraz ich dystrybucji we wspólnocie monastycznej według zasady: „każdemu według jego potrzeb", ideał wyrzekania się rzeczy zbędnych $^{7}$; ideał ścisłej ascezy materialnej (continentia), według którego należy poprzestawać wyłącznie na rzeczach pożytecznych/koniecznych co do pożywienia i ubrania ${ }^{8}$; obowiązek pracy na utrzymanie ${ }^{9}$; oraz zakaz indywidualnego udzielania jałmużny przez członka wspólnoty monastycznej ${ }^{10}$.

Podobne przepisy monastyczne, dotyczące przestrzegania ubóstwa monastycznego we wspólnocie św. Marcina w Marmoutier, spotykamy u Sulpicjusza Sewera (nieposiadanie przez mnichów niczego na własność ${ }^{11}$, niepodejmowanie pracy zarobkowej, i poprzestawanie wyłącznie na ofiarności ludzkiej) ${ }^{12}$. Jak zauważa A. de Vogüé, ten ostatni zapis jest o tyle ciekawy, że sulpicjańskie Dialogi były swoistym reportażem z życia mnichów w Egipcie, odnośnie

\footnotetext{
${ }^{1}$ Por. De Vogüé, Povertà, DIP VII 262.

${ }^{2}$ Augustinus, De moribus Ecclesiae catholicae I 31, 67, NBA 13/1, 98.

${ }^{3}$ Por. tenże, Regula ad servos Dei 1, 3, NBA 7/2, 30.

${ }^{4}$ Por. tamże 1, 2, NBA 7/2, 30; zob. Dz 4, 32-35.

${ }^{5}$ Por. Basilius, Regulae fusius tractatae 8-9, PG 31, 933-944, tłum. J. Naumowicz: Reguły dtuższe: ŹM 6, Kraków 1995, 81-89; jak zaznacza J. Naumowicz (ŹM 6, s. 81, przyp. 103), Bazyli mówiąc o as-

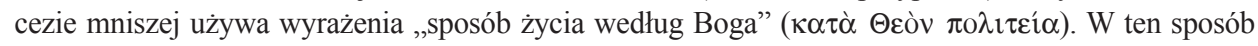
Bazyli określał życie ascetyczne, traktując je jako doskonałe życie chrześcijańskie. Podobne wyrażenia

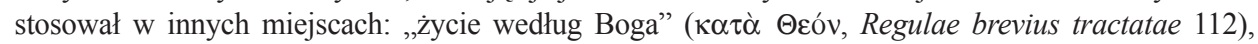

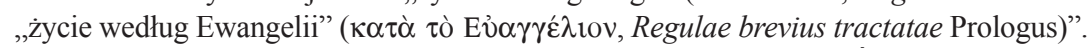

${ }^{6}$ Basilius, Regulae fusius tractatae 29-30, PG 31, 989-993, ŹM 6, 129-131; tenże, Regulae brevius tractatae 92, PG 31, 1145-1148, ŹM 6, 280-281.

${ }^{7}$ Por. tenże, Regulae brevius tractatae 129, PG 31, 1169, ŹM 6, 306; tamże, 187, PG 31, 1207, ŹM 6, 345-346; zob. Mt 10, 10; Łk 10, 4.

${ }^{8}$ Por. tenże, Regulae fusius tractatae 9, PG 31, 941-944, ŹM 6, 86-89; tenże, Regulae brevius tractatae 126, PG 31, 1167, ŹM 6, 304; tamże 134, PG 31, 1171, ŹM 6, 308-309.

${ }^{9}$ Por. tenże, Regulae fusius tractatae 37, PG 31, 1009-1016, ŹM 6, 240-241; tenże, Regulae brevius tractatae 61, PG 31, 1123, ŹM 6, 257-258.

${ }^{10}$ Por. tenże, Regulae brevius tractatae 89, PG 31, 1143, ŹM 6, 278-279; tamże 100, PG 31, 1151, ŹM 6, 286-287.

${ }^{11}$ Por. Sulpitius Severus, De vita beati Martini 10, PL 20, 166B-166D, thum. P.J. Nowak, ŹM 8, Kraków 1995, 65-66.

${ }^{12}$ Por. tenże, Dialogi 3, 14, PL 20, 219C-220C, tłum. P.J. Nowak, ŹM 8, 182-183.
} 
ubóstwa których Sulpicjusz nie poczynił praktycznie jakichkolwiek uwagg ${ }^{13}$. Także Hieronimowy przekład pachomiańskich pism ascetycznych podkreślał pogardę mnichów wobec rzeczy materialnych ${ }^{14}$ i nieposiadanie przez mnichów niczego na własność ${ }^{15}$. W pierwotnej leryńskiej Regule Czterech Ojców wyrzeczenie się dóbr materialnych było podkreślane u zaczynających ten rodzaj ascezy bogatych postulantów ${ }^{16}$ oraz mnichów z innych zakonów wstępujących pod obediencję monastyczną św. Honorata z Lerynu ${ }^{17}$. Natomiast w Drugiej Regule Ojców (obowiązującej w monasterze w Lerynie od ok. 427 r. $)^{18}$, wyrzeczenie się dóbr materialnych zostało zaznaczone jako obowiązek wszystkich mnichów leryńskich, gdyż miało ono stanowić podstawową instytucję życia wspólnego i być wyrazem miłości wspólnotowej ${ }^{19}$. Także według norm monastycznych, wyznaczonych przez Jana Kasjana, wstępujący do monasteru powinien wyzbyć się wszelkich pieniędzy i świeckiego wyposażenia, przywdziać zunifikowany habit monastyczny - jako wyraz radykalnego wyrzeczenia się doczesności i stać się drugim ubogim Chrystusem pośród innych ubogich mnichów ${ }^{20}$. Wzorem ubóstwa monastycznego pozostawał Chrystus i jego uniżenie się przy wcieleniu się w człowieka: dlatego też Kasjan łączył ubóstwo Chrystusa (paupertas Christi) z jego uniżeniem / pokorą / małością (humilitas Christi) ${ }^{21}$.

Jak zauważa A. de Vogüé, w promowanym modelu mnicha w Kościele zachodnim $\mathrm{V}$ wieku, cnoty ubóstwa i uniżenia były nierozerwalne, tak jak we wzorze mnichów - Jezusie Chrystusie. Twórcom reguł monastycznych chodziło tutaj o wyrażenie dwóch wymiarów tego samego uniżenia: pierwsze pozostawałoby na poziomie wyrzeczenia zewnętrznego (wyrzeczenie się dóbr materialnych), drugie byłoby wewnętrznym-duchowym, jako wyrzeczenie się samego siebie (praktyka cnót pokory, małości oraz bycie posłusznym wobec przełożonego). Dlatego monastyczne ogołocenie z dóbr (nuditas) to inne okre-

${ }^{13}$ Por. De Vogüé, Povertà, DIP VII 264.

${ }^{14}$ Por. Pachomius, Regula patris nosti Pachomii hominis Dei (łac. przekład Hieronima ze Strydonu) 49, PL 23, 70A-70B, thum. A. Bober, ŹM 11 (Pachomiana Latina), Kraków 1996, 137-138.

${ }^{15}$ Por. tamże 98, PL 23, 75B, ŹM 11, 148; tamże 106, PL 23, 75D, ŹM 11, 149; tamże 113, PL 23, 76B, ŹM 11, 150.

${ }^{16}$ Por. Regula sanctorum Serapionis, Macarii, Paphnutii et alterius Macarii 2, 29-35, PL 103, 438A, tłum. K. Bielawski, ŹM 3, Kraków 1994, 44.

${ }^{17}$ Por. tamże 4, 11-12, PL 103, 440A, ŹM 3, 48.

${ }^{18}$ J. Piłat (Wstęp. Wczesne reguty monastyczne z Galii, ŹM 3, 16-29), sugeruje, że po śmierci św. Honorata w 427 r., wraz ze zmianą przełożonego w monasterze leryńskim (następcą Honorata został św. Maksym) dokonała się prawdopodobnie także zmiana reguły wspólnoty, a nowe wskazania dla mnichów leryńskich zostały nazwane Druga Reguła Ojców (Alia partum regula ad monachos).

${ }^{19}$ Por. Alia partum regula ad monachos 5-6, PL 103, 442D-444A, thum. K. Bielawski, ŹM 3, 53-55.

${ }^{20}$ Por. Joannes Cassianus, De coenobiorum institutis 4, 3-6, PL 49, 155A-160A; tamże 4, 13 14, PL 49, 167A-170A; tamże 4, 19, PL 49, 178B-180A.

${ }^{21}$ Por. tamże 4, 5, PL 49, 159A; tamże 4, 37, PL 49, 197C-198A; tamże 10, 19, PL 49, 384C-385C. 
ślenie ubóstwa monastycznego (paupertas), które wyprzedza i generuje uniżenie (humilitas). To co miało być wyrażeniem pewnego procesu duchowego, na początku VI wieku stało się wymogiem prawnym: w Regułach św. Cezarego z Arles wyrzeczenie się własności zostało nałożone na postulantów jako prawne zobowiązanie wobec Kościoła, które należało własnoręcznie podpisać2 ${ }^{22}$.

W nauce Ojców Kościoła i pisarzy chrześcijańskich Kościoła Zachodniego w IV i w V wieku możemy wyróżnić dwa zasadnicze podejścia do kwestii posiadania-bogactwa-ubóstwa: realistyczne i pesymistyczne. Tendencją wspólną dla obu modeli było przekonanie o powszechnym przeznaczeniu dóbr materialnych, co wynikało z wiary, że posiadają one jedynego Stworzyciela, a ludzie są jedynie doczesnymi użytkownikami dóbr materialnych. W ujęciu realistycznym dla ogółu chrześcijan był propagowany przez Ojców model godziwego nabywania, posiadania i użytkowania bogactwa. Samo posiadanie dóbr materialnych jest godziwe, zalecane jest udzielanie jałmużny z rzeczy zbywających i niekoniecznych. Wszyscy chrześcijanie byli też zachęcani do wystrzegania się chciwości i lichwy.

W ujęciu pesymistycznym, dla chętnych był głoszony ideał ascetycznego podejścia do własności. Dobra materialne, choć stworzone przez Boga, są jednak dla ludzi źródłem nieustannych pokus i wad, szczególnie chciwości i bałwochwalstwa. Stąd monastycyzm zalecał ascetyczne podejście do dóbr doczesnych. Wyróżniamy w nim dwie tendencje dotyczące ustosunkowania się do kwestii posiadania: anachorecką i cenobicką. Dla anachoretów, na wzór św. Antoniego pustelnika, posiadanie było możliwe i godziwe, dobra są wytwarzane przez pracę rąk własnych, a to co zbywa i jest niekonieczne, powinno być przeznaczane na jałmużnę dla potrzebujących. Modelem bardziej rozpowszechnionym w Kościele Zachodnim IV-V wieku był monastycyzm cenobicki. Dla cenobitów indywidualne posiadanie było niemożliwe, dobra monasteru posiadała wspólnota. Wobec dóbr materialnych należało żywić ascetyczną pogardę, wyrzeczenie i minimalnie z nich korzystać. Według norm św. Pachomiusza, dostosowanych dla cenobitów zachodnich przez kolejnych zakonodawców, dobra materialne pozostawały wyłączną własnością wspólnoty: pojedynczy cenobita nie posiadał niczego na własność, o jakimkolwiek użytkowaniu dóbr materialnych i o zaspakajaniu potrzeb materialnych wszystkich mnichów decydował monastyczny przełożony.

Istniała także heterodoksyjna wersja podejścia do bogactw w duchu modelu pesymistycznego, propagowana $\mathrm{w} I V / \mathrm{V}$ w. przez ruch pelagian. Ich zdaniem, wszyscy chrześcijanie winni wyzbyć się własności, obowiązkowo żyć w ubóstwie jako jedynym, przewidzianym dla chrześcijan sposobie po-

\footnotetext{
${ }^{22}$ Por. De Vogüé, Povertà, DIP VII 266-267.
} 
dejścia do dóbr materialnych. Co najbardziej chyba charakterystyczne, w IV i V wieku praktycznie zanikła w Kościele na Zachodzie optymistyczna wizja postrzegania dóbr materialnych. Nie spotykamy zatem w pismach Ojców Kościoła Zachodniego opinii, według której uznawaliby oni (jak w III wieku np. Klemens Aleksandryjski) bogactwa za narzędzie do uświęcenia i za dowód opieki Bożej w zamian za pobożne życie.

\section{WEALTH AND POVERTY IN THE FOURTH AND FIFTH CENTURY CHURCH}

\section{(Summary)}

I considered the different views regarding the issues of possession, wealth and poverty in the fourth and fifth century. I focused on the concepts of the fifth-century theologian (St. Ambrose, the Bishop of Milan, St. Augustine the Bishop of Hippo), pioneers of the western monastic theology and also the earliest monastic theologians and the heterodox pelagianist writers. They regarded soteriological perspective of Christianity. In that early period the socio-economic view did not constitute a doctrine. We can distinguish two essential approaches to the issue of possession in the teaching of the Church Fathers in the fourth and fifth century: a realistic and a pessimistic attitude. (The optimistic version regarded the possession of wealth as the result of Divine Protection and as a reward for pious Christian life. Both those models presumed that all the earthly goods were created by God and that people are only the temporary stewards of the goods given them for use. The realistic approach emphasized that everything which God has made was good and there was nothing wrong with owning possessions but it denounced the unjust means by which it is sometimes achieved or used. The pessimistic approach of Anchorites (monasticism, orthodox and heterodox ascetics) accepted the possession of goods which were made with one's own hands. Everything which was not necessary should be given as alms. Coenobitic monks didn't have anything of their own because everything belonged to the monastery. Their superior decided how everything could be used. The heterodox followers of Pelagius condemned shared of private property at all, and shared the view that voluntarily poverty was the only possible way for Christian. 
